Abstracta Iranica

Revue bibliographique pour le domaine irano-aryen

Volume 32-33 | 2013

Comptes rendus des publications de 2009-2010

\title{
Pierre Lory. Souffrir pour la vérité selon l'ésotérisme chiite de Rajab Borsī
}

\section{Mathieu Terrier}

\section{(2) OpenEdition \\ 1 Journals}

Édition électronique

URL : http://journals.openedition.org/abstractairanica/40306

DOI : 10.4000/abstractairanica.40306

ISSN : 1961-960X

\section{Éditeur :}

CNRS (UMR 7528 Mondes iraniens et indiens), Éditions de l'IFRI

\section{Édition imprimée}

Date de publication : 1 décembre 2013

ISSN : 0240-8910

\section{Référence électronique}

Mathieu Terrier, «Pierre Lory. Souffrir pour la vérité selon l'ésotérisme chiite de Rajab Borsī », Abstracta Iranica [En ligne], Volume 32-33 | 2013, document 366, mis en ligne le 01 juillet 2016, consulté le 26 septembre 2020. URL : http://journals.openedition.org/abstractairanica/40306 ; DOI : https://doi.org/ 10.4000/abstractairanica.40306

Ce document a été généré automatiquement le 26 septembre 2020.

Tous droits réservés 


\title{
Pierre Lory. Souffrir pour la vérité selon l'ésotérisme chiite de Rajab Borsī
}

\author{
Mathieu Terrier
}

\section{RÉFÉRENCE}

Pierre Lory. « Souffrir pour la vérité selon l'ésotérisme chiite de Rajab Borsī », in :

Mohammad-Ali Amir-Moezzi, Meir M. Bar-Asher, Simon Hopkins, éds., Le shī'isme imā mite quarante ans après. Hommage à Etan Kohlberg. Turnhout, Brepols, 2009, p. 315-323.

1 Nombre d'exégètes sunnites ont interprété la douleur exprimée par Marie dans le Coran (19:23) comme causée par la préscience des conséquences tragiques de la mission de Jésus. Comment la pensée chiite a-t-elle médité l'échec historique de la mission de 'Alī et de ses successeurs? P. Lory présente ici l'apport de Rajab Borsī, théosophe imāmite du XV $\mathrm{XV}^{\mathrm{e}}$ s., qui voit dans l'apparition des Imāms une dimension victoriale. Son argumentation lui a valu déjà de son vivant d'être taxé d'« exagération » (g்ulūw) en milieux chiites. Or, Borsī tient fort à se dissocier de ceux qui « exagèrent » dans leur amour pour les Imāms, à la manière des chrétiens pour Jésus, au point de remettre en cause la transcendance absolue de Dieu, la préséance de Muhammad et les prescriptions de la šarǐa $a$. Lui-même se situe dans la tendance duodécimaine ancienne, concevant les Imāms comme des existants prééternels, à la fois porteurs et contenus du Livre annoncé, des théophanies permettant la «vision de Dieu» sans anthropomorphisme. L'A. souligne l'hésitation des autorités chiites à taxer de ġutūw un tel ésotérisme, partagé par maints penseurs duodécimains au cours de l'histoire. Comme il le montre enfin, il n'est jusqu'à l'interprétation triomphaliste de la souffrance des Imams chez Borsī qui ne trouve encore des échos chez les auteurs chiites modernes. 


\section{AUTEURS}

MATHIEU TERRIER

Paris 